\title{
An Ayurveda Gargle Regimen in Management of Radiotherapy-induced Oral Mucositis
}

\author{
Pankaj Wanjarkhedkar ${ }^{1, \odot}$ Sonali Pingley ${ }^{2}$ Shaileshkumar Shende ${ }^{2}$ Dhananjay Kelkar ${ }^{3}$ \\ Amit Parasnis $^{3}$ Mahesh Sambhus ${ }^{3} \quad$ Girish Phadake ${ }^{3} \quad$ Sachin Hingmire $^{4}$ Padmaj Kulkarni ${ }^{4}$ \\ Chetan Deshmukh ${ }^{4}$
}

\author{
${ }^{1}$ Department of Ayurveda and Integrative Medicine, Deenanath \\ Mangeshkar Hospital and Research Center, Pune, Maharashtra, \\ India \\ 2Department of Radiation Oncology, Deenanath Mangeshkar \\ Hospital and Research Center, Pune, Maharashtra, India \\ ${ }^{3}$ Department of Surgical Oncology, Deenanath Mangeshkar \\ Hospital and Research Center, Pune, Maharashtra, India \\ ${ }^{4}$ Department of Medical Oncology, Deenanath Mangeshkar Hospital \\ and Research Center, Pune, Maharashtra, India
}

\author{
Address for correspondence Pankaj Wanjarkhedkar, MD Ayurveda, \\ Department of Ayurveda and Integrative Medicine, Deenanath \\ Mangeshkar Hospital and Research Center, Near Mhatre Bridge, \\ Erandawne, Pune 411004, Maharashtra, India \\ (e-mail:drwpankaj@gmail.com).
}

South Asian J Cancer 2021;9:250-252.

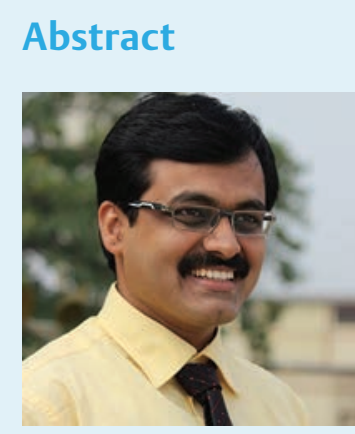

Dr. Pankaj Wanjarkhedkar

Keywords

- oral mucositis

- Ayurveda gargle regimen

- sapthachhadadi gandoosham
Background Radiotherapy-induced oral mucositis (RIOM) in patients with head and neck cancer may lead to significant morbidity. OM may result in erythema, ulceration, and pseudomembrane formation. The usual time of onset is second or third week of radiotherapy (RT), after the doses of 16 to $18 \mathrm{~Gy}$. OM may cause severe pain, significant weight loss, increased resource use, interruption or discontinuation of the treatment, and added cost of supportive care.

Materials and Methods Patients who underwent RT and chemoradiation (CTRT) for head and neck squamous cell carcinoma (HNSCC) from 2015 to 2016 were included. The patients who were treated with the add-on Ayurveda gargle regimen (AGR) of sapthachhadadi gandoosham were evaluated against patients treated with standard symptomatic care (SSC).

Statistical Analysis Chi-square test was used to compare the difference between the two groups in the present study with SPSS (SPSS version 20 for Windows package SPSS Science, Chicago, IL, USA). software.

Result Grade III to IV OM was lower in the AGR group when compared with the SSC group $(p<0.001)$. Onset of OM was significantly delayed in patients from the AGR group $(p<0.001)$.

Conclusion The AGR with sapthachhadadi gandoosham is effective in delaying the onset and reducing severity of OM in HNSCC, without compromising the rate of locoregional recurrence.

\section{Introduction}

Oral mucositis (OM) is one of the most common acute toxicities in patients with neck squamous cell carcinoma (HNSCC),

\footnotetext{
How to cite this article: Wanjarkhedkar P, Pingley S, Shende S, Kelkar D, Parasnis A, Sambhus M, Phadake G, Hingmire S, Kulkarni P, Deshmukh C. An Ayurveda Gargle Regimen in Management of Radiotherapy - induced Oral Mucositis South Asian J Cancer 2021;9(4):250-252.
}

undergoing radiation/radiotherapy (RT) or chemoradiation (CTRT).

OM may cause significant morbidity during RT in HNSCC patients, which is one of the most common acute adverse (c) 2021. MedIntel Services Pvt Ltd.

This is an open access article published by Thieme under the terms of the Creative Commons Attribution-NonDerivative-NonCommercial-License, permitting copying and reproduction so long as the original work is given appropriate credit. Contents may not be used for commercial purposes, or adapted, remixed, transformed or built upon. (https://creativecommons.org/licenses/by-nc-nd/4.0/).

Thieme Medical and Scientific Publishers Private Ltd A-12, Second Floor, Sector -2, NOIDA -201301, India 
effects of RT. OM may result in erythema, ulceration, pseudomembrane formation. The usual time of onset is second or third week of RT after the doses of 16 to $18 \mathrm{~Gy}$. OM is associated with severe pain, significant weight loss, increased resource use, interruption or discontinuation of the treatment, and added cost of supportive care. Preventive strategies are, therefore, valuable. ${ }^{1}$

Ayurveda, the ancient Indian system of medicine, has traditionally recommended topical gargle termed "gandoosham" in Sanskrit for the management of mucositis in general. ${ }^{2}$ This low-cost regimen may be an effective intervention to reduce the incidence and severity of OM and, thus, may positively contribute in the management of RT-induced OM in HNSCC.

\section{Materials and Methods}

Patients who received RT and CTRT for HNSCC from 2015 to 2016 were reviewed. Comparative analysis of the patients who were treated with the add-on Ayurveda gargle regimen (AGR) (-Table 1 ) and patients on chlorhexidine gluconate $0.2 \%$ weight/volume gargle as standard symptomatic care (SSC) was done. This analysis included patients of either gender, from the age of 18 years to 70 years, with HNSCC including oral cavity, oropharynx, and nasopharynx undergoing RT or CTRT. Patients with recurrent HNSCC were included if they had not received RT previously.

\section{Method of Use}

Patients in the AGR group were following gargling with sapthach hadadi gandoosham $20 \mathrm{~mL}$, diluted in $100 \mathrm{~mL}$ water just before use. The median frequency of gargling per day was 6 times (range 4-10). The gargles were advised from week 1 of RT for 7 weeks in the AGR group.

Patients were clinically examined weekly during the period of RT/CTRT and were followed-up for 3 months at regular intervals for post-RT acute toxicity. The electronic Lent Soma Scale was used to assess acute RT toxicity. ${ }^{15}$

Table 1 Composition of ready to use Indian Food and Drug Administration-approved GMP (good manufacturing practice)certified Ayurveda gargle

\begin{tabular}{|c|c|}
\hline \multicolumn{2}{|c|}{ Sapthachhadadi gandoosham } \\
\hline Alstonia scholaris & Induces cellular immune response ${ }^{3}$ \\
\hline Vertiveria zizanioides & Antifungal ${ }^{4}$ \\
\hline Trichosanthes dioca & $\begin{array}{l}\text { Anti-inflammatory, }{ }^{5} \text { wound healing, } \\
\text { antiulcer }^{6}\end{array}$ \\
\hline Cyperus rotundus & Antimicrobial, antioxidant ${ }^{7}$ \\
\hline Terminalia chebula & Antimicrobial, ${ }^{3}$ antiadherent ${ }^{8}$ \\
\hline Solanum xanthocarpum & Analgesic $^{9}$ \\
\hline Picrorhiza kurroa & Antiulcer ${ }^{10}$ \\
\hline Santalum album & Antiviral, anticancer ${ }^{11}$ \\
\hline Glycyrrhiza glabra & Heals oral mucositis ${ }^{12-14}$ \\
\hline Cassia fistula & Antimicrobial \\
\hline
\end{tabular}

Patients in both the groups received saline and baking soda gargle as prophylactic treatment. Once mucositis was developed, treatment prescribed in both the groups was NSAIDs (non steroidal anti inflammatory drugs), topical anesthetics, and steroids as per the standard of care.

Patients were followed till completion of 3 years post RT to detect any locoregional/systemic recurrences.

\section{Results}

Out of 62 patients, 32 were treated with add-on AGR and 30 patients were on SSC. Patients received either type of RT-conventional radiotherapy (CRT) or intensity-modulated radiation therapy (IMRT). CRT was received by $46.7 \%$ patients in the SSC group and 65.6\% patients in the AGR group, while those treated with IMRT were $53.3 \%$ patients in the SSC group and $34.4 \%$ patients in the AGR group.

The field of irradiation was unilateral for $26.7 \%$ patients in the SSC group and $28.1 \%$ patients in the AGR group, while it was bilateral for $73.3 \%$ patients in the SSC group and $71.9 \%$ patients in the AGR group.

The average dose of RT was similar in both the groups $(63.66 \pm 5.55 \mathrm{~Gy}$ in the SSC group and $63.35 \pm 4.63 \mathrm{~Gy}$ in the AGR group).

Grade III OM was observed in $43.3 \%$ patients in the SSC group and in only $6.2 \%$ patients in the AGR group $(p<0.001)$. Grade III dysphagia was reported in $56.7 \%$ patients in the SSC group as compared with only $15.6 \%$ patients in the AGR group ( $p<0.001)$. Thus, the need of nasogastric (NG) feeding tube was reduced in AGR group $(p<0.05)$.

The onset of OM in the AGR group with CTRT was week 4 to week 5 , and in the SSC group it was toward the end of week $2(p<0.001)$.

Weekly cisplatin was administered concurrently in $63.3 \%$ and56.25\% patients as standard of care in the SSC and AGR groups, respectively. An average dose of $200 \mathrm{mg}$ cisplatin concurrently was received by 19 patients in the AGR group and 18 in the SSC group.

RT was completed by $32 / 32$ patients in the study group while in the control group $28 / 30$ patients completed the treatment.

The rate of recurrence at the end of 3 years was similar in both the groups (33.3\% in the SSC group and $28.1 \%$ in the AGR group). OM and dysphagia were significantly reduced in the $\operatorname{AGR}$ group $(p<0.002)$.

\section{Discussion}

Sapthachhadadi gandoosham has been documented as gargle for mucositis in ancient Indian doctrines of Ayurveda, and is presently known to have antimicrobial, antiviral, anti-inflammatory, antioxidant, anticancer, antiadherent, and antiulcer properties in various published biomedical researches. The wound healing and cellular immune responsive action would have contributed to the observed therapeutic role in radiation-induced OM.

Ayurveda gargle regime (AGR) is cost-effective and easy to use. AGR is observed to be effective in the management of 
OM and dysphagia, and in reducing need of NG tube feeding. Thus, it has improved quality of life in HNSCC patients undergoing RT and reduced the possibility of added cost of supportive and symptomatic care.

However, small sample size and nonrandomized study remain as the limitations of the present study. Randomized study with a larger sample is recommended.

\section{Conclusion}

The AGR with sapthachhadadi gandoosham is effective in delaying the onset and reducing the severity of OM in HNSCC without compromising the rate of locoregional recurrence.

\section{Financial Support and Sponsorship}

None.

Conflicts of Interest

None declared.

\section{References}

1 Elting LS, Cooksley CD, Chambers MS, Garden AS. Risk, outcomes, and costs of radiation-induced oral mucositis among patients with head-and-neck malignancies. Int J Radiat Oncol Biol Phys 2007;68(4):1110-1120

2 Paradkar H, ed. Mukharog-pratishedha: chapter 22 verse 103. Commentary Sarvangasundar of Arundatta and Ayurveda Rasayana of Hemadri on Ashtanghridayam of Vagbhata, Uttarsthana. Varanasi, India: Choukhambha Orientalia, 2005; 857

3 Iwo MI, Soemardji AA, Retnoningrum DS, Sukrasno UUM, U UM. Immunostimulating effect of pule (Alstonia scholaris $\mathrm{L}$. R.Br., Apocynaceae) bark extracts. Clin Hemorheol Microcirc 2000;23(2-4):177-183

4 Snigdha M, Kumar SS, Mohapatra S, Deepa C. An overview on Vetiveria zizanioides. Res J Pharm Biol Chem Sci 2013;4:777-783
5 Kumar N, Singh S, Manvi, Gupta R. Trichosanthes dioica Roxb.: An overview. Pharmacogn Rev 2012;6(11):61-67. doi: 10.4103/0973-7847.95886. PMID: 22654406; PMCID: PMC3358970.

6 Kumar N, Singh S, Manvi, Gupta R. Trichosanthes dioica Roxb.: an overview. Pharmacogn Rev 2012;6(11):61-67

7 Kilani-Jaziri S, Bhouri W, Skandrani I, et al. Phytochemical, antimicrobial, antioxidant and antigenotoxic potentials of Cyperus rotundus extracts. S Afr J Bot. 2011;77(3):767-776

8 Carounanidy U, Satyanarayanan R, Velmurugan A. Use of an aqueous extract of Terminalia chebula as an anticaries agent: a clinical study. Indian J Dent Res 2007;18(4):152-156

9 Bhadoria N, Gunwal MK, Suryawanshi H, Sonarkar SS. Antiadherence and antimicrobial property of herbal extracts (Glycyrrhiza glabra and Terminalia chebula) on Streptococcus mutans: an in vitro experimental study. J Oral Maxillofac Pathol 2019;23(1):73-77

10 Kumar S, Pandey AK. Medicinal attributes of Solanum xanthocarpum fruit consumed by several tribal communities as food: an in vitro antioxidant, anticancer and anti HIV perspective. BMC Complement Altern Med 2014;14:112

11 Banerjee D, Maity B, Nag SK, Bandyopadhyay SK, Chattopadhyay S. Healing potential of Picrorhiza kurroa (Scrofulariaceae) rhizomes against indomethacin-induced gastric ulceration: a mechanistic exploration. BMC Complement Altern Med 2008;8:3

12 Santha S, Dwivedi C. Anticancer effects of sandalwood (Santalum album) Anticancer Res 2015;35(6):3137-3145

13 Najafi S, Koujan SE, Manifar S, Kharazifard MJ, Kidi S, Hajheidary S. Preventive effect of Glycyrrhiza glabra extract on oral mucositis in patients under head and neck radiotherapy: a randomized clinical trial. J Dent (Tehran) 2017;14(5):267-274

14 Ghalayani P, Emami H, Pakravan F, Nasr Isfahani M. Comparison of triamcinolone acetonide mucoadhesive film with licorice mucoadhesive film on radiotherapy-induced oral mucositis: a randomized double-blinded clinical trial. Asia Pac J Clin Oncol 2017;13(2):e48-e56

15 LENT SOMA scales for all anatomic sites. Int J Radiat Oncol Biol Phys 1995;31(5):1049-1091

\section{Best of ASCO India 2021 Conference}

$8_{\text {th }}$ to $11^{\text {th }}$ July 2021

Program Director - Dr M Vamshi Krishna, Director of Medical Oncology and BMT AIG Hospital, Hyderabad drmvkrishnaonco@gmail.com 995977112

Conference Managers - Kavina Creations

kashish@kavinacreations.com 9819025850 